\title{
Pandemic Economics: The 1918 Influenza and Its Modern-Day Implications
}

Thomas A. Garrett

\begin{abstract}
Many predictions of the economic and social costs of a modern-day pandemic are based on the effects of the influenza pandemic of 1918. Despite killing 675,000 people in the United States and 40 million worldwide, the influenza of 1918 has been nearly forgotten. The purpose of this paper is to provide an overview of the influenza pandemic of 1918 in the United States, its economic effects, and its implications for a modern-day pandemic. The paper provides a brief historical background as well as detailed influenza mortality statistics for cities and states, including those in the Eighth Federal Reserve District, that account for differences in race, income, and place of residence. Information is obtained from two sources: (i) newspaper articles published during the pandemic and (ii) a survey of economic research on the subject. (JEL I1, No, R0)
\end{abstract}

Federal Reserve Bank of St. Louis Review, March/April 2008, 90(2), pp. 75-93.

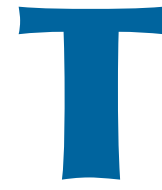

he possibility of a worldwide influenza pandemic in the near future is of growing concern for many countries around the globe. The World Bank estimates that a global influenza pandemic would cost the world economy $\$ 800$ billion and kill tens of millions of people (Brahmbhatt, 2005). Researchers at the U.S. Centers for Disease Control and Prevention (CDC) calculate that deaths in the United States could reach 207,000 and the initial cost to the economy could approach $\$ 166$ billion, or roughly 1.5 percent of GDP (Meltzer, Cox, and Fukuda, 1999). The U.S. Department of Health and Human Services paints a more dire pictureup to 1.9 million dead in the United States and initial economic costs near $\$ 200$ billion (U.S. Department of Health and Human Services, 2005). The long-run costs of a modern-day influenza pandemic are expected to be much greater.

Although researchers and public officials can only speculate on the likelihood of a global influenza pandemic, many of the worst-case scenario predictions for a current pandemic are based on the global influenza pandemic of 1918. That pandemic killed 675,000 people in the United States (nearly 0.8 percent of the 1910 population), a greater number than U.S. troop deaths in World War I $(116,516)$ and World War II $(405,399)$ combined. ${ }^{1}$ Roughly 40 million people died worldwide from the early spring of 1918 through the late spring of $1919 .^{2}$ In all of recorded history, only the Black Death that occurred throughout Europe from 1348 to 1351 is estimated to have killed more people (roughly 60 million) over a similar time period (Bloom and Mahal, 1997).

The years 1918 and 1919 were difficult not only because of the influenza pandemic, but because these years also marked the height of

\footnotetext{
1 See Potter (2001) for a discussion of 1918 influenza pandemic mortalities. U.S. troop mortality data can be found at www.fas.org/sgp/crs/natsec/RL32492.pdf.

2 Although 40 million is the commonly accepted number of worldwide deaths from the pandemic, it is likely an underestimate given the lack of adequate recordkeeping in many parts of the world.
}

Thomas A. Garrett is an assistant vice president and economist at the Federal Reserve Bank of St. Louis. Lesli S. Ott provided research assistance.

(C) 2008, The Federal Reserve Bank of St. Louis. Articles may be reprinted, reproduced, published, distributed, displayed, and transmitted in their entirety if copyright notice, author name(s), and full citation are included. Abstracts, synopses, and other derivative works may be made only with prior written permission of the Federal Reserve Bank of St. Louis. 
U.S. involvement in World War I. Given the magnitude and the concurrence of both the influenza pandemic and World War I, one would expect volumes of research on the economic effects of each event. Although significant literature on the economic consequences of World War I does exist (Rockoff, 2004), the scope of research on the economic effects of the 1918 influenza pandemic is scant at best. Most research has focused on the health and economic outcomes of descendents of pandemic survivors and the mortality differences across socioeconomic classes. (See, for example, Keyfitz and Flieger, 1968; Noymer and Garenne, 2000; Almond, 2006; and Mamelund, 2006.) Certainly an event that caused 40 million worldwide deaths in a year should be closely examined not only for its historical significance, but also for what we can learn (in the unfortunate chance the world experiences another influenza pandemic).

This paper discusses some of the economic effects of the 1918 influenza pandemic in the United States. The first section discusses demographic differences in pandemic mortalities: Were deaths higher in cities than in rural areas? Did deaths differ by race? Detailed influenza mortality data at various geographic and demographic levels at the time of the pandemic are available. The presentation of mortality data series allows for an almost unlimited number of comparisons and analyses that afford the reader the opportunity to study the available data and generate his own analyses and conclusions in addition to those presented here.

Evidence on the effects of the pandemic on business and industry is obtained from newspaper articles printed during the pandemic, with most of the articles appearing in newspapers from the Eighth Federal Reserve District cities of Little Rock, Arkansas, and Memphis, Tennessee. Newspaper articles from the fall of 1918 were used because of the almost complete absence of economic data from the era, such as data on income, employment, sales, and wages. This absence of data, especially at local levels (e.g., city and county), is a likely reason for the scarcity of economic research on the subject, although several studies that have used available economic data are reviewed here.

Although the influenza pandemic occurred nearly 90 years ago in a world that was much different from today's, the limited economic data and more readily available mortality data from the time of the event can be used to make reasonable inferences about the economic and social consequences of a modern-day pandemic. Despite technological advances in medicine and greater health coverage throughout the twentieth century, deaths from a modern-day pandemic are also likely to be related to race, income, and place of residence. Thus, the geographic and demographic differences in pandemic mortalities from 1918 can shed light on the possible effects of a modernday pandemic, a point that is taken up in the final section of the paper.

\section{OVERVIEW OF THE 1918 INFLUENZA PANDEMIC}

The influenza pandemic in the United States occurred in three waves during 1918 and 1919. ${ }^{3}$ The first wave began in March 1918 and lasted throughout the summer of 1918. The more devastating second and third waves (the second being the worst) occurred in the fall of 1918 and the spring of 1919 as the pandemic spread across the country:

Spanish influenza moved across the United States in the same way as the pioneers had, for it followed their trails which had become railroads...the pandemic started along the axis from Massachusetts to Virginia...leaped the Appalachians...positioned along the inland waterways...it jumped clear across the plains and the Rockies to Los Angeles, San Francisco, and Seattle. Then, with secure bases on both coasts...took its time to seep into every niche and corner of America. (Crosby, 2003, pp. 63-64)

But the pandemic's impact on communities and regions was not uniform across the country. For example, Pennsylvania, Maryland, and

\footnotetext{
3 For much more information on the influenza pandemic, including its origins, see Crosby (2003) and Barry (2004).
} 
Colorado had the highest mortality rates, but these states had very little in common. Arguments have been made that mortality rates were lower in later-hit cities because officials in these cities were able to take precautions to minimize the impending influenza, such as closing schools and churches and limiting commerce. The virulence of the influenza, like a typical influenza, weakens over time, so the influenza that struck the East Coast became somewhat weaker by the time it struck the West Coast. But these reasons cannot completely explain why some cities and regions experienced high mortality rates while others were barely hit with the influenza. ${ }^{4}$

The global magnitude and spread of the pandemic was exacerbated by World War I, which itself is estimated to have killed roughly 10 million civilians and 9 million troops. Not only did the mass movement of troops from around the world lead to the spread of the disease, tens of thousands of Allied and Central Power troops died as a result of the influenza pandemic rather than combat (Ayres, 1919). Although combat deaths in World War I did increase the mortality rates for participating countries, civilian mortality rates from the influenza pandemic of 1918 were typically much higher. For the United States, estimates of combat-related troop mortalities are about one-tenth that of civilian mortalities from the 1918 influenza pandemic.

Mortality rates from a typical influenza tend to be the greatest for the very young and the very old. What made the 1918 influenza unique was that mortality rates were the highest for the segment of the population aged 18 to 40, and more so for males than females of this age group. In general, death was not caused by the influenza virus itself, but by the body's immunological reaction to the virus: Individuals with the strongest immune systems were more likely to die than individuals with weaker immune systems. ${ }^{5}$ One

\footnotetext{
4 Much research has been conducted over the past decades to provide insights into why the pandemic had such different effects on different regions of the country (see, for example, Crosby, 2003, and Barry, 2004). One commonly held reason is the response of local governments to the influenza in their communities, e.g., partial versus full quarantines.

5 The lungs typically filled with fluid and the victim drowned or died of pneumonia. See Barry (2004).
}

source reports that, of 272,500 male influenza deaths in 1918, nearly 49 percent were aged 20 to 39 , whereas only 18 percent were under age 5 and 13 percent were over age 50.6 The fact that males aged 18 to 40 were the hardest hit by the influenza had serious economic consequences for the families that had lost their primary breadwinner.

Despite the severity of the pandemic, it is reasonable to say that the influenza of 1918 has almost been forgotten as a tragic event in American history. This is not good, as learning from past pandemics may be the only way to reasonably prepare for any future pandemics. Several factors may explain why the influenza pandemic of 1918 has not received a notable place in U.S. history. ${ }^{7}$

First, the pandemic occurred at the same time as World War I. The influenza struck soldiers especially hard, given their living conditions and close contact with highly mobile units. Much of the news from the day focused on wartime events overseas and the current status of American troops. Thus, the pandemic and World War I were seen almost as one event rather than two separate events. Second, diseases of the day such as polio, smallpox, and syphilis were incurable and a permanent part of society. Influenza, on the other hand, swept into communities, killed members of the population, and was gone. Finally, unlike polio and smallpox, no famous people of the era died from the influenza; thus, there was no public perception that even the politically powerful and rich and famous were susceptible to the virus.

Despite its lack of historical prominence, the influenza pandemic of 1918 created significant economic and social effects, even if these were short-lived. In select areas, increasing body counts overwhelmed city and medical officials. In some cities, such as Philadelphia, bodies lay along the streets and in morgues for days, similar to medieval Europe during the Black Death. In light of the potential economic turmoil and human suffering, an understanding of the state and fed-

\footnotetext{
6 The 272,500 deaths are from a sample of about 30 states. See Crosby (2003, p. 209).

7 See Crosby (2003, pp. 319-22).
} 
eral government response to the 1918 pandemic may also shed some light into what government at any level can do, if anything, to prevent or minimize a modern-day pandemic.

\section{PANDEMIC MORTALITIES IN THE UNITED STATES}

Data on mortalities from the 1918 influenza pandemic are found in Mortality Statistics, an annual publication that is released by the U.S. Census Bureau. ${ }^{8}$ Mortalities resulting from hundreds of causes of death are listed (depending on the level of data aggregation) and are also broken down, in some cases, by age, race, and sex. Data are available at the national, state, and municipal levels and may be available by week, month, and year. In terms of coverage, "(a)ll death rates are based on total deaths, including deaths of nonresidents, deaths in hospitals and institutions, and deaths of soldiers, sailors, and marines" (U.S. Department of Commerce, Bureau of the Census, 1922, p. 9). ${ }^{9}$ The mortality rates used in this study represent deaths from both influenza and pneumonia in a given year because "it is not believed to be best to study separately influenza and the various forms of pneumonia...for doubtless many cases were returned as influenza when the deaths were caused by pneumonia and vice versa" (U.S. Department of Commerce, Bureau of the Census, 1921, p. 28). ${ }^{10}$

Although Mortality Statistics provides a remarkable number of statistics, a major disadvantage of the earlier reports is that, in the 1910s, data coverage is for only 75 to 80 percent of the total population. This is because the U.S. Census Bureau acquired the mortality data over time from a registration area that consisted of a growing group of states. So mortality data for certain states are not consistently available over time. For the

\footnotetext{
8 Copies of the historical reports are available at the CDC, National Center for Health Statistics, or at www.cdc.gov/nchs/products/ pubs/pubd/vsus/historical/historical.htm. Mortalities are likely to be underestimated, as overburdened health professionals stopped recording deaths during the peak of the pandemic.

9 Hereafter, this reference will be cited as Mortality Statistics 1920.

${ }^{10}$ Hereafter, this reference will be cited as Mortality Statistics 1919.
}

purposes of this article, influenza mortality data for the 1910s are available for about 30 states and encompass, on average, about 79.5 percent of the U.S. population. A casual look at the states that did and did not report mortality information does not reveal any systematic differences across each group of states with regard to population, income, and race. So the available mortality statistics are unlikely to provide a biased picture of influenza mortalities.

The following sections report select influenza mortality data at various levels of data aggregation (city and state), by race (white and non-white), and by residence (urban versus rural). The abundance of mortality statistics makes it impossible to use all existing data in a single report. However, the statistics used here do reveal some general mortality patterns that provide insights into which groups of people may be most/least affected by a modern-day pandemic, as well as how influenza mortalities differed across cities and states.

\section{State and City Pandemic Mortalities}

Pandemic mortality rates (per 100,000) for 27 states are shown in Table 1 for 1918 and 1919. The mortality rate for 1915 is also included and the ratio of 1918 mortalities to 1915 mortalities is calculated to reveal the deaths in 1918 relative to a non-pandemic year. ${ }^{11}$ For the states shown in Table 1, Pennsylvania, Maryland, and New Jersey had the highest mortality rates in 1918, whereas Michigan, Minnesota, and Wisconsin had the lowest. The pandemic also lasted throughout the spring of 1919, so the ranking of states in 1918 does not reflect total mortalities in each state for the entire pandemic (although the rankings do remain similar).

The ratio of the 1918 mortality rate to the 1915 mortality rate ranges from a low of 3.2 (Indiana and New York) to a high of 6.5 (Montana). One caveat is that an equal increase in mortalities for a lower-population state and a higher-population state will result in a greater mortality ratio for the

\footnotetext{
${ }^{11}$ The non-pandemic year is assumed to be a normal influenza year. Later analyses of city influenza mortality rates use actual data on normal and excess mortality rates rather than assuming all years except 1918 and 1919 were normal.
} 


\section{Table 1}

Influenza Mortality Rates (per 100,000) for Select States

\begin{tabular}{|c|c|c|c|c|c|c|c|c|}
\hline State & $\begin{array}{c}1910 \\
\text { Population }\end{array}$ & $\begin{array}{c}\text { Area } \\
\left(\text { miles }^{2}\right)\end{array}$ & $\begin{array}{c}\text { Population } \\
\text { density }\end{array}$ & $\begin{array}{c}1915 \\
\text { Mortality } \\
\text { rate }\end{array}$ & $\begin{array}{c}1918 \\
\text { Mortality } \\
\text { rate }\end{array}$ & $\begin{array}{c}1919 \\
\text { Mortality } \\
\text { rate }\end{array}$ & $\begin{array}{c}\text { Ratio of } \\
1918 \text { and } \\
1915 \text { rates }\end{array}$ & $\begin{array}{l}1918 \\
\text { Rank }\end{array}$ \\
\hline California & $2,377,549$ & 155,652 & 15.27 & 102.1 & 537.8 & 214.7 & 5.3 & 15 \\
\hline Colorado & 799,024 & 103,658 & 7.71 & 170.5 & 766.5 & 253.5 & 4.5 & 5 \\
\hline Connecticut & $1,114,756$ & 4,820 & 231.28 & 169.2 & 767.7 & 224.5 & 4.5 & 4 \\
\hline Indiana & $2,700,876$ & 36,045 & 74.93 & 126.1 & 408.1 & 213.7 & 3.2 & 24 \\
\hline Kansas & $1,690,949$ & 81,774 & 20.68 & 116.7 & 474.4 & 188.1 & 4.1 & 22 \\
\hline Kentucky & $2,289,905$ & 40,181 & 56.99 & 118.0 & 537.3 & 284.6 & 4.6 & 16 \\
\hline Maine & 742,371 & 29,895 & 24.83 & 166.0 & 589.4 & 229.2 & 3.6 & 14 \\
\hline Maryland & $1,295,346$ & 9,941 & 130.30 & 171.0 & 803.6 & 238.4 & 4.7 & 2 \\
\hline Massachusetts & $3,366,416$ & 8,039 & 418.76 & 170.7 & 726.7 & 207.8 & 4.3 & 8 \\
\hline Michigan & $2,810,173$ & 57,480 & 48.89 & 111.9 & 389.3 & 192.2 & 3.5 & 27 \\
\hline Minnesota & $2,075,708$ & 80,858 & 25.67 & 100.3 & 390.5 & 166.9 & 3.9 & 26 \\
\hline Missouri & $3,293,335$ & 68,727 & 47.92 & 144.2 & 476.6 & 206.1 & 3.3 & 20 \\
\hline Montana & 376,053 & 146,201 & 2.57 & 117.7 & 762.7 & 225.4 & 6.5 & 6 \\
\hline New Hampshire & 430,572 & 9,031 & 47.68 & 153.2 & 751.6 & 231.6 & 4.9 & 7 \\
\hline New Jersey & $2,537,167$ & 7,514 & 337.66 & 163.4 & 769.4 & 226.5 & 4.7 & 3 \\
\hline New York & $9,113,614$ & 47,654 & 191.25 & 185.2 & 598.2 & 233.7 & 3.2 & 12 \\
\hline North Carolina & $2,206,287$ & 48,740 & 45.27 & 148.4 & 503.1 & 234.4 & 3.4 & 18 \\
\hline Ohio & $4,767,121$ & 40,740 & 117.01 & 135.2 & 494.3 & 222.0 & 3.7 & 19 \\
\hline Pennsylvania & $7,665,111$ & 44,832 & 170.97 & 168.9 & 883.1 & 236.5 & 5.2 & 1 \\
\hline Rhode Island & 542,610 & 1,067 & 508.54 & 185.8 & 681.2 & 239.2 & 3.7 & 9 \\
\hline South Carolina & $1,515,400$ & 30,495 & 49.69 & $131.9^{*}$ & 632.6 & 291.5 & $4.8^{*}$ & 10 \\
\hline Tennessee & $2,184,789$ & 41,687 & 52.41 & $135.3^{*}$ & 476.0 & 234.8 & $3.5^{*}$ & 21 \\
\hline Utah & 373,351 & 82,184 & 4.54 & 119.5 & 508.8 & 270.8 & 4.3 & 17 \\
\hline Vermont & 355,956 & 9,124 & 39.01 & 150.0 & 597.2 & 228.9 & 4.0 & 13 \\
\hline Virginia & $2,061,612$ & 40,262 & 51.20 & 131.1 & 621.1 & 267.2 & 4.7 & 11 \\
\hline Washington & $1,141,990$ & 66,836 & 17.09 & 78.4 & 411.5 & 187.9 & 5.2 & 23 \\
\hline Wisconsin & $2,333,860$ & 55,256 & 42.24 & 119.6 & 405.6 & 178.5 & 3.4 & 25 \\
\hline
\end{tabular}


Table 2

\section{Correlations of State Characteristics with Influenza Mortalities}

\begin{tabular}{lccc} 
& $\mathbf{1 9 1 5}$ Mortality rate & $\mathbf{1 9 1 8}$ Mortality rate & Ratio of $\mathbf{1 9 1 8}$ and $\mathbf{1 9 1 5}$ rates \\
\hline Density (population/miles $\left.{ }^{2}\right)$ & $0.632^{*}$ & $0.447^{*}$ & -0.097 \\
Area $\left(\mathrm{miles}^{2}\right)$ & $-0.566^{*}$ & -0.253 & 0.350 \\
Population & 0.250 & 0.031 & -0.236
\end{tabular}

NOTE: *Denotes statistical significance at 5 percent level or better. Correlations are based on the data in Table $1(n=27)$.

lower-population state because the increase in mortalities is a greater percentage of its population. Nevertheless, a comparison of 1915 mortality rates with those in 1918 and 1919 clearly reveals how much more severe the 1918 influenza was relative to influenza in a non-pandemic year.

Evidence suggests that influenza mortality rates had no relationship with state economic conditions, climate, or geography (see Crosby, 2003, and Brainerd and Siegler, 2003). After providing a survey of anecdotal evidence and conducting statistical analyses, Brainerd and Siegler (2003, p. 7) conclude that "the statistical evidence also supports the notion of influenza mortality as an exogenous shock to the population." However, because influenza is spread by close human contact, influenza infection and mortality rates are commonly greater in more densely populated areas.

It thus serves as an interesting exercise to see whether there is a relationship between pandemic mortalities and state population size and population density. It is also worth exploring whether the relationships are different in a pandemic year compared with a non-pandemic year. Table 2 thus presents pairwise correlations (and their statistical significance) between state population, area, and population density and 1915 mortality rates, 1918 mortality rates, and the ratio of the two mortality rates.

The correlations shown in Table 2 reveal that mortality rates in 1915 were greater in more densely populated states (0.632), but lower in larger states (-0.566). State size had no significant correlation with 1918 mortality rates, but population density was correlated with 1918 mortality rates (0.447). Note, however, that the correlation between mortality rates and density is less for 1918 mortalities than for 1915 mortalities. This finding, in addition to the fewer significant correlations (albeit just one fewer), suggest that state size and population density had less influence on mortality rates in 1918 than in 1915. Thus, as suggested by earlier research, the location of individuals was less of a factor in dying from the 1918 influenza than from a non-pandemic influenza. ${ }^{12}$ Furthermore, the ratio of mortality rates had no relationship with state size, population, or population density, as seen in the last column of Table 2.

Mortality statistics for 49 cities are listed in Table 3. As seen in the state-level statistics, influenza mortalities in U.S. cities during the pandemic were three to five times higher, on average, than during a non-pandemic year (1915). There is slightly more variation in 1918 mortality rates across cities $(\sigma=182)$ than across states $(\sigma=146)$. The cities with the highest 1918 mortality rates (Pittsburgh, Scranton, and Philadelphia) are all located in Pennsylvania, and the cities with the lowest rates (Grand Rapids, Minneapolis, and Toledo) are all located in the Midwest.

It is possible to get an idea of the influenza's effect on rural areas versus urban areas by calculating the average 1918 mortality in all cities in a state (for which mortality data were available) and then dividing by the state-level mortality rate. ${ }^{13}$

\footnotetext{
${ }^{12}$ See Crosby (2003).

${ }^{13}$ Mortality rates for 64 cities (49 of which appear in Table 3) were used in the calculations. The other 15 cities were not included in Table 3 because of missing data. The mortality rates for these 15 cities can be obtained from the author.
} 


\section{Table 3}

Influenza Mortality Rates (per 100,000) for Select Cities

\begin{tabular}{|c|c|c|c|c|c|c|}
\hline City & $\begin{array}{c}1910 \\
\text { Population }\end{array}$ & $\begin{array}{c}1915 \\
\text { Mortality rate }\end{array}$ & $\begin{array}{c}1918 \\
\text { Mortality rate }\end{array}$ & $\begin{array}{l}1919 \\
\text { Mortality rate }\end{array}$ & $\begin{array}{c}\text { Ratio of } 1918 \\
\text { and } 1915 \text { rates }\end{array}$ & $\begin{array}{l}1918 \\
\text { Rank }\end{array}$ \\
\hline Albany, New York & 100,253 & 187.1 & 679.1 & 244.8 & 3.6 & 22 \\
\hline Atlanta, Georgia & 154,839 & 165.7 & 478.4 & 291.4 & 2.9 & 40 \\
\hline Baltimore, Maryland & 558,485 & 207.1 & 836.5 & 230.6 & 4.0 & 7 \\
\hline Birmingham, Alabama & 132,685 & 158.1 & 843.6 & 319.1 & 5.3 & 6 \\
\hline Boston, Massachusetts & 670,585 & 214.6 & 844.7 & 256.3 & 3.9 & 5 \\
\hline Bridgeport, Connecticut & 102,054 & 206.0 & 825.4 & 272.3 & 4.0 & 8 \\
\hline Buffalo, New York & 423,715 & 168.7 & 637.5 & 206.2 & 3.8 & 28 \\
\hline Cambridge, Massachusetts & 104,839 & 157.3 & 676.5 & 180.0 & 4.3 & 23 \\
\hline Chicago, Illinois & $2,185,283$ & 172.7 & 516.6 & 191.5 & 3.0 & 35 \\
\hline Cincinnati, Ohio & 353,591 & 163.4 & 605.4 & 253.2 & 3.7 & 29 \\
\hline Cleveland, Ohio & 560,663 & 155.1 & 590.9 & 260.5 & 3.8 & 30 \\
\hline Columbus, Ohio & 181,511 & 136.5 & 451.9 & 213.5 & 3.3 & 43 \\
\hline Dayton, Ohio & 116,577 & 142.7 & 525.2 & 154.6 & 3.7 & 33 \\
\hline Denver, Colorado & 213,381 & 184.8 & 727.7 & 228.5 & 3.9 & 15 \\
\hline Detroit, Michigan & 465,766 & 148.1 & 413.4 & 242.4 & 2.8 & 46 \\
\hline Fall River, Massachusetts & 119,295 & 213.5 & 799.7 & 216.8 & 3.7 & 9 \\
\hline Grand Rapids, Michigan & 112,571 & 100.0 & 282.7 & 93.8 & 2.8 & 49 \\
\hline Indianapolis, Indiana & 233,650 & 146.7 & 459.4 & 240.6 & 3.1 & 42 \\
\hline Jersey City, New Jersey & 267,779 & 211.2 & 756.6 & 317.0 & 3.6 & 13 \\
\hline Kansas City, Missouri & 248,381 & 176.1 & 718.1 & 301.1 & 4.1 & 17 \\
\hline Los Angeles, California & 319,198 & 87.4 & 484.5 & 186.8 & 5.5 & 38 \\
\hline Lowell, Massachusetts & 106,294 & 191.3 & 696.1 & 198.4 & 3.6 & 19 \\
\hline Memphis, Tennessee & 131,105 & 179.3 & 666.1 & 340.6 & 3.7 & 24 \\
\hline Milwaukee, Wisconsin & 373,857 & 158.9 & 474.1 & 187.7 & 3.0 & 41 \\
\hline Minneapolis, Minnesota & 301,408 & 121.6 & 387.7 & 169.4 & 3.2 & 48 \\
\hline Nashville, Tennessee & 110,364 & 179.9 & 910.2 & 301.0 & 5.1 & 4 \\
\hline New Haven, Connecticut & 133,605 & 207.9 & 768.0 & 212.3 & 3.7 & 11 \\
\hline New Orleans, Louisiana & 339,075 & 245.8 & 768.6 & 333.7 & 3.1 & 10 \\
\hline New York, New York & $4,766,883$ & 212.1 & 582.5 & 265.8 & 2.7 & 31 \\
\hline Newark, New Jersey & 347,469 & 146.6 & 680.4 & 213.3 & 4.6 & 21 \\
\hline Oakland, California & 150,174 & 98.6 & 496.6 & 238.2 & 5.0 & 36 \\
\hline Omaha, Nebraska & 124,096 & 150.9 & 660.8 & 191.8 & 4.4 & 26 \\
\hline Paterson, New Jersey & 125,600 & 159.4 & 683.6 & 235.7 & 4.3 & 20 \\
\hline Philadelphia, Pennsylvania & $1,549,008$ & 189.2 & 932.5 & 222.9 & 4.9 & 3 \\
\hline Pittsburgh, Pennsylvania & 533,905 & 260.1 & $1,243.6$ & 431.8 & 4.8 & 1 \\
\hline Portland, Oregon & 207,214 & 69.6 & 448.2 & 246.4 & 6.4 & 44 \\
\hline Providence, Rhode Island & 224,326 & 191.4 & 737.4 & 253.3 & 3.9 & 14 \\
\hline Richmond, Virginia & 127,628 & 209.9 & 661.0 & 269.5 & 3.1 & 25 \\
\hline Rochester, New York & 218,149 & 121.8 & 522.7 & 152.8 & 4.3 & 34 \\
\hline San Francisco, California & 416,912 & 130.6 & 647.7 & 283.3 & 5.0 & 27 \\
\hline Scranton, Pennsylvania & 129,867 & 223.7 & 985.7 & 247.5 & 4.4 & 2 \\
\hline Seattle, Washington & 237,194 & 74.7 & 425.5 & 189.8 & 5.7 & 45 \\
\hline Spokane, Washington & 104,402 & 91.9 & 487.4 & 210.7 & 5.3 & 37 \\
\hline St. Louis, Missouri & 687,029 & 156.7 & 536.5 & 202.3 & 3.4 & 32 \\
\hline St. Paul, Minnesota & 214,744 & 127.8 & 480.6 & 145.9 & 3.8 & 39 \\
\hline Syracuse, New York & 137,249 & 120.5 & 704.6 & 155.9 & 5.8 & 18 \\
\hline Toledo, Ohio & 168,497 & 126.8 & 401.0 & 181.9 & 3.2 & 47 \\
\hline Washington, D.C. & 331,069 & 189.8 & 758.8 & 225.9 & 4.0 & 12 \\
\hline Worcester, Massachusetts & 145,986 & 188.9 & 727.1 & 248.9 & 3.8 & 16 \\
\hline
\end{tabular}

NOTE: Mortality rates are from Mortality Statistics 1920 and include mortalities from influenza and pneumonia. 


\section{Table 4}

\section{City Influenza Mortality Rate Relative to State Mortality Rate (1918)}

\begin{tabular}{lc} 
State & $\begin{array}{c}\text { Average of cities } \\
\text { relative to state }\end{array}$ \\
\hline Michigan & 0.89 \\
Colorado & 0.95 \\
California & 1.01 \\
New York & 1.02 \\
Maryland & 1.04 \\
Massachusetts & 1.06 \\
Connecticut & 1.07 \\
Washington & 1.11 \\
Pennsylvania & 1.11 \\
Minnesota & 1.11 \\
Indiana & 1.13 \\
New Jersey & 1.16 \\
Wisconsin & 1.17 \\
Virginia & 1.17 \\
Ohio & 1.19 \\
Missouri & 1.32 \\
Kansas & 1.58 \\
Tennessee & 1.66 \\
\hline
\end{tabular}

These ratios are shown in Table 4. A ratio greater than 1 suggests influenza deaths were, on average, greater in a state's cities than in the rural areas of the state-and vice versa for a ratio less than 1 .

As seen in Table 4, most of the ratios are greater than 1, with some much greater than 1 (Missouri, Kansas, and Tennessee), thus revealing that cities in their respective state had higher mortality rates than rural areas of that state. This finding supports the positive correlation between population density and influenza mortalities shown in Table 2.

\section{Influenza Mortalities and Race}

Influenza mortalities by race are available for some cities in the United States, although the racial breakdown is not as detailed as it is for modern-day mortality statistics. Mortality statistics for 1918 are provided on the basis of white and non-white. Table 5 presents a breakdown of white and non-white mortality rates (per 100,000 for each racial group) for 14 U.S. cities. For each racial group, influenza mortality rates for 1915 are also included so a comparison can be made between a pandemic year and a non-pandemic year. The first six columns of Table 5 clearly show that non-white influenza mortalities are higher than white influenza mortalities in both pandemic and non-pandemic years (except for Kansas City in 1918). Whites experienced relatively higher mortality during the pandemic year 1918 (compared with the non-pandemic year 1915) than did non-whites.

It is likely that racial differences in influenza mortality rates reflect, to some degree, differences in population density (as seen in Table 2) and geography (as seen in Table 4). Data on white and non-white populations as well as rural and urban residences for several decennial Census years are shown in Table 6. In 1910, the great majority of the urban population (having a higher population density than rural areas) in the United States was white (over 90 percent). This offers some explanation as to why whites as a group had a much larger increase in influenza mortalities during the pandemic than did non-whites. But, the decline in the strength of the mortality/density relationship in 1918 compared with that of 1915 (see Table 2) suggests that urban location alone cannot account for the relatively large increase in influenza mortalities among whites.

What does this imply if an influenza pandemic struck today? The last two columns of Table 6 reveal that the non-white population in the United States has become much more urban (27 percent in 1910 and 91 percent in 2000) compared with the white population (49 percent in 1910 and 75 percent in 2000). However, the fact that both racial groups are becoming more urban does not bode well for either group because population density will certainly be a significant determinant of mortality. However, a modern-day pandemic may result in greater non-white mortality rates because a greater percentage of the non-white population in the United States lives in urban areas. 
Table 5

Influenza Mortality Rate By Race and City, 1915 and 1918

\begin{tabular}{|c|c|c|c|c|c|c|c|c|}
\hline City & $\begin{array}{c}\text { White } \\
\text { mortality } \\
\text { rate } \\
1918\end{array}$ & $\begin{array}{c}\text { Non-white } \\
\text { mortality } \\
\text { rate } \\
1918\end{array}$ & $\begin{array}{c}\text { White, } \\
\text { as percent } \\
\text { of non-white } \\
1918\end{array}$ & $\begin{array}{c}\text { White } \\
\text { mortality } \\
\text { rate } \\
1915\end{array}$ & $\begin{array}{c}\text { Non-white } \\
\text { mortality } \\
\text { rate } \\
1915\end{array}$ & $\begin{array}{c}\text { White, } \\
\text { as percent } \\
\text { of non-white } \\
1915\end{array}$ & $\begin{array}{c}\text { White, } \\
1915, \\
\text { as percent } \\
\text { of white } \\
1918\end{array}$ & $\begin{array}{c}\text { Non-white } \\
1915, \\
\text { as percent } \\
\text { of non-white } \\
1918\end{array}$ \\
\hline Birmingham & 676.3 & $1,101.8$ & 61.4 & 114.7 & 225.0 & 51.0 & 17.0 & 20.4 \\
\hline Atlanta & 362.2 & 730.3 & 49.6 & 99.3 & 305.5 & 32.5 & 27.4 & 41.8 \\
\hline Indianapolis & 440.6 & 615.2 & 71.6 & 132.9 & 264.5 & 50.2 & 30.2 & 43.0 \\
\hline $\begin{array}{c}\text { Kansas City, } \\
\text { Missouri }\end{array}$ & 758.5 & 701.6 & 108.1 & 216.9 & 445.2 & 48.7 & 28.6 & 63.5 \\
\hline Louisville & $1,012.3$ & $1,015.5$ & 99.7 & 111.2 & 369.6 & 30.1 & 11.0 & 36.4 \\
\hline New Orleans & 679.7 & $1,019.0$ & 66.7 & 165.1 & 472.3 & 35.0 & 24.3 & 46.3 \\
\hline Baltimore & 787.8 & $1,086.9$ & 72.5 & 169.3 & 406.0 & 41.7 & 21.5 & 37.4 \\
\hline Memphis & 608.0 & 766.0 & 79.4 & 111.4 & 290.7 & 38.3 & 18.3 & 38.0 \\
\hline Nashville & 884.0 & $1,060.4$ & 83.4 & 130.0 & 288.7 & 45.0 & 14.7 & 27.2 \\
\hline Dallas & 572.8 & 845.8 & 67.7 & $67.9 *$ & $149.8^{*}$ & $45.3^{*}$ & $11.9^{*}$ & $17.7^{*}$ \\
\hline Houston & 485.8 & 618.5 & 78.5 & $98.0^{*}$ & $143.9^{*}$ & $68.1^{*}$ & $20.2^{*}$ & $23.3^{*}$ \\
\hline Norfolk & 739.8 & 835.6 & 88.5 & 98.8 & 305.8 & 32.3 & 13.4 & 36.6 \\
\hline Richmond & 555.8 & 883.4 & 62.9 & 131.5 & 367.0 & 35.8 & 23.7 & 41.5 \\
\hline Washington, D.C. & 694.3 & 942.0 & 73.7 & 129.9 & 354.9 & 36.6 & 18.7 & 37.7 \\
\hline
\end{tabular}

NOTE: *Mortality rates for Dallas and Houston for 1915 are 1916 and 1917 figures, respectively.

\section{Table 6}

\section{Location and Race, 1890-2000}

\begin{tabular}{lcccc} 
Year & $\begin{array}{c}\text { White } \\
\text { as percent of } \\
\text { U.S. urban population }\end{array}$ & $\begin{array}{c}\text { Non-white } \\
\text { as percent of } \\
\text { U.S. urban population }\end{array}$ & $\begin{array}{c}\text { Percent of } \\
\text { white population } \\
\text { that is urban }\end{array}$ & $\begin{array}{c}\text { Percent of } \\
\text { non-white population } \\
\text { that is urban }\end{array}$ \\
\hline 1890 & 93.35 & 6.65 & 35.06 & 17.54 \\
1910 & 93.45 & 6.55 & 48.73 & 27.26 \\
1930 & 92.18 & 7.82 & 57.63 & 43.20 \\
1950 & 89.93 & 10.07 & 64.29 & 61.64 \\
1970 & 86.24 & 13.76 & 72.45 & 80.71 \\
1990 & 76.88 & 23.12 & 72.02 & 88.21 \\
2000 & 71.45 & 28.55 & 75.17 & 90.59
\end{tabular}

SOURCE: Population data are from Historical Statistics of the United States, U.S. Census. 
Table 7

Influenza Mortalities-Cities in Eighth District States

\begin{tabular}{|c|c|c|c|c|}
\hline Year & $\begin{array}{c}\text { Total influenza deaths } \\
\text { per } 100,000\end{array}$ & $\begin{array}{c}\text { Total "excess" } \\
\text { influenza deaths }\end{array}$ & $\begin{array}{c}\text { "Normal" } \\
\text { influenza deaths }\end{array}$ & $\begin{array}{l}\text { Ratio of total deaths } \\
\text { to "normal" deaths }\end{array}$ \\
\hline \multicolumn{5}{|c|}{ Louisville, Kentucky } \\
\hline 1915 & 156.5 & 359 & 340 & 1.06 \\
\hline 1916 & 185.2 & 427 & 342 & 1.25 \\
\hline 1917 & 209.5 & 485 & 366 & 1.33 \\
\hline 1918 & $1,012.9$ & 2,357 & 1,287 & 1.83 \\
\hline 1919 & 357.8 & 837 & 322 & 2.59 \\
\hline 1920 & 197.2 & 463 & 322 & 1.44 \\
\hline \multicolumn{5}{|c|}{ Memphis, Tennessee } \\
\hline 1915 & 179.3 & 263 & 261 & 1.01 \\
\hline 1916 & N/A & $\mathrm{N} / \mathrm{A}$ & $\mathrm{N} / \mathrm{A}$ & $\mathrm{N} / \mathrm{A}$ \\
\hline 1917 & 219.0 & 335 & 282 & 1.19 \\
\hline 1918 & 666.1 & 1,040 & 312 & 3.33 \\
\hline 1919 & 340.6 & 542 & 316 & 1.71 \\
\hline 1920 & 311.4 & 506 & 369 & 1.37 \\
\hline \multicolumn{5}{|c|}{ Nashville, Tennessee } \\
\hline 1915 & 179.9 & 206 & 209 & 0.98 \\
\hline 1916 & N/A & N/A & N/A & N/A \\
\hline 1917 & 188.6 & 219 & 230 & 0.95 \\
\hline 1918 & 910.2 & 1,063 & 249 & 4.27 \\
\hline 1919 & 301.0 & 354 & 234 & 1.51 \\
\hline 1920 & 301.9 & 357 & 232 & 1.54 \\
\hline \multicolumn{5}{|c|}{ St. Louis, Missouri } \\
\hline 1915 & 156.7 & 1,144 & 1,191 & 0.96 \\
\hline 1916 & 200.4 & 1,480 & 1,212 & 1.22 \\
\hline 1917 & 227.0 & 1,696 & 1,216 & 1.39 \\
\hline 1918 & 536.5 & 4,054 & 1,262 & 3.21 \\
\hline 1919 & 202.3 & 1,546 & 1,207 & 1.28 \\
\hline 1920 & 262.9 & 2,032 & 1,198 & 1.70 \\
\hline
\end{tabular}

NOTE: Column 1: Total influenza deaths per 100,000 are from Mortality Statistics 1920. Column 2: The number of influenza deaths was computed by multiplying the death rates in column 1 by the city population for the respective year. Column 3: This variable uses information on excess influenza deaths. Excess deaths from influenza are reported in U.S. Treasury and Public Health Service (1930, Table A). In the preceding report, excess deaths (on an annual basis) per 100,000 are defined as the excess over the median monthly rate for the period 1910-16 prior to July 1, 1919, and as the excess over the median monthly rate for the period 1921-27 after July 1 , 1919. For the purpose here, the rates on an annual basis were converted to a monthly basis, then converted to levels, and then summed for the year to get a measure of the total number of excess deaths for the city for the year. It is this number that is subtracted from total deaths (column 2) to get the number of "normal" deaths shown in column 3. Column 4: Column 2 divided by column 3.

Of course, race and place of residence (and population density) are not the only factors that are likely to influence mortality rates. Access to health care is likely to be critical (assuming health professionals themselves are not decimated by the pandemic). So it stands to reason that mortality rates in urban areas may be somewhat miti- gated given the relatively greater access to health care than in rural areas. Ability to pay, which relates to income, may also be important. Urban areas, on average, tend to have greater incomes, but this is an average and ignores those individuals with low incomes in urban areas who cannot afford health care. The ability of free clinics and 
Table 7, cont'd

Influenza Mortalities-Cities in Eighth District States

\begin{tabular}{|c|c|c|c|c|}
\hline Year & $\begin{array}{l}\text { Total influenza deaths } \\
\text { per } 100,000\end{array}$ & $\begin{array}{c}\text { Total "excess" } \\
\text { influenza deaths }\end{array}$ & $\begin{array}{c}\text { "Normal" } \\
\text { influenza deaths }\end{array}$ & $\begin{array}{l}\text { Ratio of total deaths } \\
\text { to "normal" deaths }\end{array}$ \\
\hline \multicolumn{5}{|c|}{ Kansas City, Missouri } \\
\hline 1915 & 176.1 & 504 & 386 & 1.31 \\
\hline 1916 & 138.7 & 408 & 397 & 1.03 \\
\hline 1917 & 205.0 & 618 & 407 & 1.52 \\
\hline 1918 & 718.1 & 2,220 & 479 & 4.64 \\
\hline 1919 & 301.1 & 954 & 429 & 2.22 \\
\hline 1920 & 353.6 & 1,147 & 489 & 2.35 \\
\hline \multicolumn{5}{|c|}{ Chicago, Illinois } \\
\hline 1915 & 172.7 & 4,220 & 4,884 & 0.86 \\
\hline 1916 & 168.4 & 4,202 & 5,000 & 0.84 \\
\hline 1917 & 201.7 & 5,137 & 5,082 & 1.01 \\
\hline 1918 & 516.6 & 13,423 & 5,433 & 2.47 \\
\hline 1919 & 191.5 & 5,075 & 4,388 & 1.16 \\
\hline 1920 & 223.9 & 6,049 & 2,893 & 2.09 \\
\hline \multicolumn{5}{|c|}{ Indianapolis, Indiana } \\
\hline 1915 & 146.7 & 420 & 383 & 1.10 \\
\hline 1916 & 153.7 & 452 & 396 & 1.14 \\
\hline 1917 & 156.6 & 472 & 301 & 1.57 \\
\hline 1918 & 459.4 & 1,420 & 467 & 3.04 \\
\hline 1919 & 240.6 & 762 & 425 & 1.79 \\
\hline 1920 & 240.9 & 782 & 432 & 1.81 \\
\hline
\end{tabular}

emergency rooms to remain open during a pandemic will be crucial to the treatment of lowerincome individuals. The final section of this article will expand on these points.

\section{Pandemic Mortalities in the States of the Eighth Federal Reserve District}

Table 7 shows available data on mortalities from 1915 to 1920 for cities located in the states of the Eighth Federal Reserve District. The first column of data contains mortality rates per 100,000 population (from Mortality Statistics 1920). The number of deaths (found by multiplying the rate in the first column by city population) is shown in the second column. The third column contains "normal" influenza deaths and was calculated by subtracting the number of excess deaths in each year from the total number of deaths shown in column 2. Normal influenza deaths reflect the number of influenza deaths absent a pandemic and are based on deviations from historical median monthly rates. ${ }^{14}$ The ratio of total deaths to normal deaths presented in column 4 provides a measure of the severity of influenza in each year relative to a normal influenza. Clearly, this ratio is much larger for the years 1918 and 1919.

The data in Table 7 allow for several interesting comparisons. First, in all cities, the ratio of total deaths to normal deaths in pandemic years was at least twice the normal rate. The ratio was over four times as high in Nashville and Kansas City, Missouri, in 1918 and at least three times as high in Memphis, St. Louis, and Indianapolis. Chicago and Louisville had the lowest ratios in 1918 (2.47 and 1.83, respectively). So, although larger cities such as Chicago had more influenza

\footnotetext{
${ }^{14}$ See the note for Table 7 for a description of how normal and excess influenza mortality rates were calculated for the 50 largest cities in the United States.
} 
Table 8

Urban/Rural Influenza Mortalities: Eighth District States and Cities

\begin{tabular}{|c|c|c|c|}
\hline Year & $\begin{array}{c}\text { State mortality rate } \\
\text { per } 100,000\end{array}$ & $\begin{array}{c}\text { Rural mortality rate } \\
\text { per } 100,000\end{array}$ & $\begin{array}{c}\text { Rural rate as percent of } \\
\text { Louisville rate }\end{array}$ \\
\hline \multicolumn{4}{|c|}{ Kentucky } \\
\hline 1915 & 118.0 & 113.9 & 72.8 \\
\hline 1916 & 152.7 & 149.3 & 80.6 \\
\hline 1917 & 144.7 & 137.8 & 65.8 \\
\hline 1918 & 537.3 & 486.8 & 48.1 \\
\hline 1919 & 284.6 & 276.7 & 77.4 \\
\hline 1920 & 197.6 & 197.6 & 100.2 \\
\hline
\end{tabular}

\begin{tabular}{cccc} 
Year & $\begin{array}{c}\text { State mortality rate } \\
\text { per } \mathbf{1 0 0 , 0 0 0}\end{array}$ & $\begin{array}{c}\text { Rural mortality rate } \\
\text { per } \mathbf{1 0 0 , 0 0 0}\end{array}$ & $\begin{array}{c}\text { Rural rate as percent of } \\
\text { Chicago rate }\end{array}$ \\
\hline IIlinois & & & N/A \\
1915 & $\mathrm{~N} / \mathrm{A}$ & $\mathrm{N} / \mathrm{A}$ & $\mathrm{N} / \mathrm{A}$ \\
1916 & $\mathrm{~N} / \mathrm{A}$ & $\mathrm{N} / \mathrm{A}$ & $\mathrm{N} / \mathrm{A}$ \\
1917 & $\mathrm{~N} / \mathrm{A}$ & 486.2 & 94.1 \\
1918 & 498.8 & 185.4 & 96.8 \\
1919 & 187.9 & 205.9 & 92.0
\end{tabular}

\begin{tabular}{cccc} 
Year & $\begin{array}{c}\text { State mortality rate } \\
\text { per } \mathbf{1 0 0 , 0 0 0}\end{array}$ & $\begin{array}{c}\text { Rural mortality rate } \\
\text { per } \mathbf{1 0 0 , 0 0 0}\end{array}$ & $\begin{array}{c}\text { Rural rate as percent of } \\
\text { Indianapolis rate }\end{array}$ \\
\hline $\begin{array}{c}\text { Indiana } \\
1915\end{array}$ & & & \\
1916 & 126.1 & 123.8 & 84.4 \\
1917 & 147.1 & 146.4 & 95.2 \\
1918 & 146.2 & 145.0 & 92.6 \\
1919 & 408.1 & 401.9 & 87.5 \\
1920 & 213.7 & 210.4 & 87.5 \\
\end{tabular}

NOTE: The rural mortality rates are for the state less the city(ies) listed. This statistic was computed by obtaining the number of influenza deaths at the state level (the first column multiplied by population) and then subtracting the number of city dead (shown in Table 7). This value was then normalized by the rural population (the difference between the state population and the city population). The final column was computed by dividing the rural mortality rate by the city mortality rate shown in the first column of Table 7 .

SOURCE: The state mortality rates are from Mortality Statistics 1920.

deaths in 1918 (and other years as well), the relative mortality of influenza in these larger cities was less than that in smaller cities such as Nashville and Kansas City.

State-level mortality rates and rural mortality rates for states located in the Eighth Federal Reserve District are shown in Table 8. The rural mortality rates are not necessarily reflective of what one thinks a rural area to be: The rural mortality rates in Table 8 are computed by subtracting the number of mortalities in a city (from Table 7) from the number of mortalities at the state level (first column of Table 8). ${ }^{15}$ Thus, for example, the rural mortality rate in Kentucky is the mortality rate for all of Kentucky except for Louisville. Certainly, there are other non-rural areas in Kentucky in addition to Louisville, but mortality

\footnotetext{
${ }^{15}$ See the note for Table 8 for more information on how the rural mortality rate was calculated.
} 
Table 8, cont'd

Urban/Rural Influenza Mortalities: Eighth District States and Cities

\begin{tabular}{|c|c|c|c|c|}
\hline Year & $\begin{array}{l}\text { State mortality rate } \\
\text { per } 100,000\end{array}$ & $\begin{array}{l}\text { Rural mortality rate } \\
\text { per } 100,000\end{array}$ & $\begin{array}{l}\text { Rural rate as percent of } \\
\text { St. Louis rate }\end{array}$ & $\begin{array}{l}\text { Rural rate as percent of } \\
\text { Kansas City rate }\end{array}$ \\
\hline \multicolumn{5}{|c|}{ Missouri } \\
\hline 1915 & 144.2 & N/A & $N / A$ & N/A \\
\hline 1916 & 167.9 & $\mathrm{~N} / \mathrm{A}$ & N/A & $\mathrm{N} / \mathrm{A}$ \\
\hline 1917 & 181.4 & 164.4 & 72.4 & 80.2 \\
\hline 1918 & 476.6 & 423.5 & 78.9 & 59.0 \\
\hline 1919 & 206.1 & 194.2 & 96.0 & 64.5 \\
\hline 1920 & 261.2 & 247.6 & 94.2 & 70.0 \\
\hline Year & $\begin{array}{c}\text { State mortality rate } \\
\text { per } 100,000\end{array}$ & $\begin{array}{c}\text { Rural mortality rate } \\
\text { per } 100,000\end{array}$ & $\begin{array}{c}\text { Rural rate as percent of } \\
\text { Memphis rate }\end{array}$ & $\begin{array}{c}\text { Rural rate as percent of } \\
\text { Nashville rate }\end{array}$ \\
\hline \multicolumn{5}{|c|}{ Tennessee } \\
\hline 1915 & $\mathrm{~N} / \mathrm{A}$ & N/A & $N / A$ & $N / A$ \\
\hline 1916 & $\mathrm{~N} / \mathrm{A}$ & $\mathrm{N} / \mathrm{A}$ & $N / A$ & $\mathrm{~N} / \mathrm{A}$ \\
\hline 1917 & 135.3 & 126.1 & 57.6 & 66.9 \\
\hline 1918 & 476.0 & 436.1 & 65.5 & 47.9 \\
\hline 1919 & 234.8 & 222.7 & 65.4 & 74.0 \\
\hline 1920 & 220.0 & 208.0 & 66.8 & 68.9 \\
\hline
\end{tabular}

data on these areas are not available. Nevertheless, because mortality rates are generally available for the largest cities in a state, the rural mortality rates are likely to provide an approximate picture of the influenza's impact on the less-populated areas of a state.

The data in Table 8-rural mortality rate relative to the city mortality rate for each state-are similar to the data presented in Table 4; but, the data in Table 8 allow for multiple-year comparisons and a comparison between "rural" and "city" rather than city and state. As Table 8 shows, the state rural rate is almost always less than the city rate (except for Kentucky in 1920), which also supports the results in Table 2 that reveal a positive correlation between population density and influenza mortalities.

Although the rural mortality rate is less than the city rate in most cases, there are differences in rates across states and over time. For example, the rural-to-city mortality ratio in Illinois averages about 94 percent, whereas the rate averages around 77 percent in Missouri. There does not appear to be, however, a consistent difference in mortality rates between pandemic years and nonpandemic years when comparing across the states, although it appears that the rural-to-city mortality ratio is substantially higher in non-pandemic years in Kansas City, Louisville, and Nashville. What one can conclude from Table 8 is that rural influenza mortality rates were typically less than city influenza rates in both pandemic and nonpandemic years, and only in the case of a few cities is there evidence that the rural-to-city mortality ratio was less in a pandemic year compared with non-pandemic years.

\section{ECONOMIC EFFECTS OF THE 1918 INFLUENZA PANDEMIC}

As mentioned earlier, the greatest disadvantage of studying the economic effects of the 1918 influenza is the lack of economic data. There are 
some academic studies that have looked at the economic effects of the pandemic using available data, and these studies are reviewed below. Given the general lack of economic data, however, a remaining source for information on (some) economic effects of the 1918 pandemic is print media. Newspapers in the Eighth Federal Reserve District cities of Little Rock and Memphis that were printed in the fall of 1918 contained information on the effects of the influenza pandemic in these cities. Piecing together anecdotal information from individual cities provides a relatively good picture of the general effects of the pandemic and the potential economic effects of a modernday pandemic.

\section{The 1918 Influenza Pandemic in the News}

This section presents headlines and summaries from articles appearing in two newspapers in Eighth Federal Reserve District cities: The Arkansas Gazette (Little Rock) and The Commercial Appeal (Memphis). Articles listing the number of sick or dead from the influenza appeared almost daily in these newspapers and other papers as well (St. Louis and Louisville, for example). Also appearing frequently were articles on church, school, and theater closings, as well as dubious remedies and cures for the influenza. ${ }^{16}$ However, articles that described the influenza's effects on the local economy were far less numerous. The several articles that appeared in the fall of 1918 that did discuss the economic impact of the influenza are summarized below.

\section{Little Rock, Arkansas}

\section{"How Influenza Affects Business."}

The Arkansas Gazette, October 19, 1918, p. 4.

- Merchants in Little Rock said their business had declined 40 percent. Others estimated the decrease at 70 percent.

- The retail grocery business was reduced by one-third.

- A department store that had been doing

\footnotetext{
${ }^{16}$ Copies of all articles are available from the author, including articles from the St. Louis Post-Dispatch and the Louisville CourierJournal.
}

$\$ 15,000$ in daily business $(\$ 200,265$ in 2006 dollars) reported that it was doing no more than half that.

- Bed rest was emphasized in the treatment of influenza. As a result, there was increased demand for beds, mattresses, and springs.

- Little Rock businesses were losing \$10,000 per day on average $(\$ 133,500$ in 2006 dollars). This was from actual loss of inventory, not a decrease in business that may have been covered by an increase in sales when the quarantine order was over. (That is, certain items could not be stored and sold at a later time.)

- The only business in Little Rock that showed an increase in sales was the drug store.

\section{Memphis, Tennessee}

"Influenza Crippling Memphis Industries." The Commercial Appeal, October 5, 1918, p. 7.

- Physicians reported they were kept too busy combating the disease to report the number of their patients and had little time to devote to other matters.

- Industrial plants were running under a great handicap. Many of them were already short of help because of the draft.

- Railway service was curtailed when, out of a total of about 400 men used in the transportation department of the Memphis Street Railway, 124 men were incapacitated.

- The Cumberland Telephone Co. reported more than one hundred operators absent from their posts. The telephone company asked that unnecessary calls be eliminated.

\section{"Tennessee Mines May Shut Down."}

The Commercial Appeal, October 18, 1918, p. 12.

- Coal mine operators reported a 50 percent decrease in production.

- Mines throughout east Tennessee and southern Kentucky were on the verge of closing down, owing to the epidemic raging through the mining camps.

- Coalfield, Tennessee, with a population of 500 , had "only 2 percent of well people." 


\section{Survey of Academic Research}

Garrett (2006) examines the immediate effect of influenza mortalities on manufacturing wages in U.S. cities and states for the period 1914-19. The testable hypothesis of the paper is that influenza mortalities had a direct impact on wage rates in the manufacturing sector in U.S. cities and states during and immediately after the 1918 influenza pandemic. The hypothesis is based on a simple economic model of the labor market: A decrease in the supply of manufacturing workers that resulted from influenza mortalities would have had the initial effect of reducing manufacturing labor supply, increasing the marginal product of labor and capital per worker, and thus increasing real wages. In the short term, labor immobility across cities and states is likely to have prevented wage equalization across the states, and a substitution away from relatively more-expensive labor to capital is unlikely to have occurred. ${ }^{17}$ Garrett (2006) finds that states and cities having had greater influenza mortalities experienced greater wage growth from 1914 to 1919-roughly 2 to 3 percentage points for a 10 percent change in per capita mortalities. Approximately 4 percent of total wage growth from 1914 to 1919 is attributed to influenza mortalities.

Brainerd and Siegler (2003) explored the impact of the influenza pandemic on state income growth for the decade after the influenza pandemic. The authors argue that states that experienced larger numbers of influenza deaths per capita would have experienced higher rates of growth in per capita income after the pandemic. States with higher influenza mortality rates would have had a greater increase in capital per worker

\footnotetext{
${ }^{17}$ The long-run effect of influenza and war mortalities on manufacturing wage growth is less clear. Although the Solow (1956) growth model suggests that capital per worker will eventually fall (due to diminishing returns to capital) and therefore decrease wages, Romer's (1986) growth model predicts capital per worker will continue to rise over time as a result of non-diminishing returns to capital, thereby increasing wages. It is also possible that the war and the pandemic decreased consumer confidence, investment, and savings, and long-term income growth of households due to the death of households' primary breadwinners. These factors would result in lower aggregate output and production, thereby decreasing the demand for labor and placing downward pressure on manufacturing wages. Finally, the higher wages would eventually be bid down as more people would be attracted to areas initially offering higher wages.
}

and thus also output per worker and higher incomes after the pandemic. Using state-level personal income estimates for 1919-21 and 1930, Brainerd and Siegler (2003) do find a positive and statistically significant relationship between statewide influenza mortality rates and subsequent state per capita income growth.

Almond (2006) explored the longer-term effect of the 1918 influenza. The author questions whether in utero exposure to the influenza had negative economic consequences for individuals later in their lives. The author's hypothesis is that an individual's health endowment is positively related to his human capital and productivity and thus also to wages and income (the fetal origins hypothesis). Using 1960-80 decennial census data, Almond (2006) found that cohorts in utero during the 1918 pandemic had reduced educational attainment, higher rates of physical disability, and lower income. Specifically, "[m]en and women show large and discontinuous reductions in educational attainment if they had been in utero during the pandemic. The children of infected mothers were up to 15 percent less likely to graduate from high school. Wages of men were 5-9 percent lower because of infection" (Almond, 2006, p. 673).

Most of the evidence indicates that the economic effects of the 1918 influenza pandemic were short term. Many businesses, especially those in the service and entertainment industries, suffered double-digit losses in revenue. Other businesses that specialized in health care products experienced an increase in revenues. Some academic research suggests that the 1918 influenza pandemic caused a shortage of labor that resulted in higher wages (at least temporarily) for workers, although no reasonable argument can be made that this benefit outweighed the costs from the tremendous loss of life and overall economic activity. Research also suggests that the 1918 influenza caused reductions in human capital for those individuals in utero during the pandemic - therefore having implications for economic activity occurring decades after the pandemic. 


\section{IMPLICATIONS FOR A MODERN-DAY PANDEMIC}

As mentioned at the beginning of this article, the potential financial costs and death tolls from a modern-day pandemic in the United States suggest an initial cost of several hundred billion dollars and the deaths of hundreds of thousands to several million people. The information presented here and information provided in two prominent publications (see Crosby, 2003, and Barry, 2004) on the 1918 influenza pandemic can be used to formulate a list of the likely economic effects of a modern-day influenza pandemic and possible ways to mitigate its severity:

- Given the positive correlation between population density and influenza mortalities, cities are likely to have greater mortality rates than rural areas. Compared with 1918, however, urban and rural areas are more connected today, which may decrease the difference in mortality rates between cities and rural areas. Similarly, a greater percentage of the U.S. population is now considered urban (about 79 percent) compared with the U.S. population at the time of the pandemic (51 percent in 1920).

- Non-white groups as a whole have a greater chance of death because roughly 90 percent of all non-whites live in urban areas (compared with about 75 percent of whites).

This correlates with lower-income individuals being more likely to die-non-white (excluding Asians) households have a lower median income $(\$ 30,858$ in 2005$)$ compared with white households $(\$ 50,784$ in 2005) Similarly, only 10 percent of whites were below the poverty level in 2005 compared with over 20 percent for various minority groups (except Asians) (DeNavas-Walt, Proctor, and Lee, 2006, Table 4).

- Urban dwellers are likely to have, on average, better physical access to quality health care; however, nearly 19 percent of the city population in the United States has no health coverage, compared with only 14 percent of the rural population (DeNavasWalt, Proctor, and Lee, 2006, Table 8). Questions remain regarding the affordability of health care and whether free-service health care providers, clinics, and emergency rooms (the most likely choices for the uninsured) are able to handle victims of the pandemic.

- Health care is irrelevant unless there are systems in place to ensure that an influenza pandemic will not incapacitate health-care provision and prevent the rapid disposal of the dead in the cities (as it did in Philadelphia in 1918, exacerbated by medical leaves during World War I). If medical staff succumbs to the influenza and facilities are overwhelmed, the duration and severity of the pandemic will be increased. In Philadelphia, for example, "the city morgue had as many as ten times as many bodies as coffins" (Crosby, 2003, p. 82).

- A greater percentage of families with life insurance would mitigate the financial effects from the loss of a family's primary breadwinner. However, life insurance is a normal good (positively correlated with income), so low-income families are less likely to be protected with insurance than are higher-income families (Cummins and Mahul, 2004).

- Local quarantines would likely hurt businesses in the short run. Employees would likely be laid off. Families with no contact to the influenza may too experience financial hardships.

- Some businesses could suffer revenue losses in excess of 50 percent. Others, such as those providing health services and products, may experience an increase in business (unless a full quarantine exists). If the pandemic causes a shortage of employees, there could be a temporary increase in wages for remaining employees in some industries. This is less likely than in 1918, however, given the greater mobility of workers that exists today. 
- Can we rely on local, state, and federal governments to help in the case of a modernday pandemic? Government has shown its inability to coordinate some disasters in the past (e.g., Hurricane Katrina). Governmental decisions at the time of the 1918 influenza also had unfortunate consequences. In fact, the decision of local officials in Philadelphia to proceed with a Liberty Bond parade during the pandemic significantly increased mortality rates. Nearly 20,000 people gathered together in downtown Philadelphia for the event. Days later, influenza mortality rates in Philadelphia soared, making Philadelphia one of the hardest hit cities during the pandemic. Officials in St. Louis (a comparable city to Philadelphia at the time), however, responded quickly to the influenza by closing nearly all public places as soon as the influenza had reached the city. As a result, influenza mortality rates were much lower than in Philadelphia.

\section{FINAL THOUGHTS}

The influenza of 1918 was the most serious epidemic in the history of the United States. Hundreds of thousands of people died and millions were infected with the highly contagious influenza virus. The possibility of a future influenza pandemic has focused research back to the 1918 pandemic as a foundational model for the likely effects of a modern-day influenza outbreak in the United States. Despite the severity of the 1918 influenza, however, there has been relatively little research done on the economic effects of the pandemic. This article has provided a concise, albeit certainly not complete, discussion and analysis of the economic effects of the 1918 influenza pandemic based on available data and research.

The influenza of 1918 was short-lived and "had a permanent influence not on the collectivities but on the atoms of human society-individuals" (Crosby, 2003, p. 323). Society as a whole recovered from the 1918 influenza quickly, but individuals who were affected by the influenza had their lives changed forever. Given our highly mobile and connected society, any future influenza pandemic is likely to be more severe in its reach, and perhaps in its virulence, than the 1918 influenza despite improvements in health care over the past 90 years. Perhaps lessons learned from the past can help mitigate the severity of any future pandemic.

An important difference between 1918 and now is that we have the CDC and similar organizations in other countries that monitor outbreaks of disease, send teams to identify and isolate diseases, and coordinate responses. ${ }^{18} \mathrm{We}$ also have national flu vaccination programs and funding. The question remains whether all of this is adequate in the event of a pandemic. A recent report from the Infectious Diseases Society of America (2005) suggests that the United States is not prepared for an influenza pandemic. Although federal, state, and local governments in the United States have started to focus on preparedness in recent years, it is fair to say that progress has been slow, especially at local levels of government. ${ }^{19}$ The key to mitigating a pandemic is the successful cooperation and planning of all levels of government, something that has not always occurred in the past. Although we are certainly more prepared for an influenza pandemic now than in 1918, there should still be concern about government's readiness and ability to protect citizens from a pandemic.

\section{REFERENCES}

Almond, Douglas. "Is the 1918 Influenza Pandemic Over? Long-Term Effects of In Utero Influenza Exposures in the Post-1940 U.S. Population."

\footnotetext{
18 The CDC's pandemic influenza plan has two parts: (i) delay or prevent the influenza from reaching the United States and (ii) if the influenza does reach the United States, minimize the rates of infection (and thus mortalities); see www pandemicflu.gov. Local governments' plans focus on minimizing the rates of infection.

${ }^{19}$ See www.pandemicflu.gov, a site managed by the U.S. Department of Health and Human Services. The lack of influenza vaccines, low production capacity, inadequate supply networks, slow government response, and poor public education are cited as problems.
} 


\section{Garrett}

Journal of Political Economy, August 2006, 114(4), pp. 672-712.

Ayres, Leonard P. The War With Germany: A Statistical Summary. Washington, DC: U.S. Government Printing Office, 1919.

Barry, John M. The Great Influenza: The Epic Story of the Deadliest Plague in History. New York: Viking, 2004.

Bloom, David E. and Mahal, Ajay S. "AIDS, Flu, and the Black Death: Impacts on Economic Growth and Well-Being," in David Bloom and Peter Godwin, eds., The Economics of HIV and AIDS: The Case of South and Southeast Asia. Delhi: Oxford University Press, 1997, pp. 22-52.

Brahmbhatt, Milan. "Avian Influenza: Economic and Social Impacts.” Washington, DC: World Bank, September 23, 2005.

Brainerd, Elizabeth and Siegler, Mark. "The Economic Effects of the 1918 Influenza Epidemic.” Discussion Paper 3791, Centre for Economic Policy Research, 2003.

Crosby, Alfred W. America's Forgotten Pandemic: The Influenza of 1918. Cambridge: Cambridge University Press, 2003.

Cummins, J. David and Mahul, Olivier. "The Demand for Insurance with an Upper Limit on Coverage." Journal of Risk and Insurance, June 2004, 71(2), pp. 253-64.

DeNavas-Walt, Carmen; Proctor, Bernadette and Lee, Cherry Hill. Income, Poverty, and Health Insurance Coverage in the United States: 2005. Washington, DC: Census Bureau, 2006; www.census.gov/prod/2006pubs/p60-231.pdf.

Garrett, Thomas A. "War and Pestilence as Labor Market Shocks: U.S. Manufacturing Wage Growth 1914-1919.” Working Paper 2006-018C, Federal Reserve Bank of St. Louis, 2006. Forthcoming in Economic Inquiry.

Infectious Diseases Society of America. "IDSA's Principles for Actions Needed to Prepare the U.S. to Effectively Respond to Interpandemic/Pandemic Influenza." March 2005; www.idsociety.org.

Keyfitz, Nathan and Flieger, Wilhelm. World Population: An Analysis of Vital Data. Chicago: University of Chicago Press, 1968.

Mamelund, Sven-Erik. “A Socially Neutral Disease? Individual Social Class, Household Wealth and Mortality from Spanish Influenza in Two Socially Contrasting Parishes in Kristiania, 1918-19." Social Science and Medicine, February 2006, 62(4), pp. 923-40.

Meltzer, Martin I.; Cox, Nancy J. and Fukuda, Keiji. "The Economic Impact of Pandemic Influenza in the United States: Priorities for Intervention." Emerging Infectious Diseases, September/October 1999, 5(5), pp. 659-71.

Noymer, Andrew and Garenne, Michel. "The 1918 Influenza Epidemic's Effects on Sex Differentials in Mortality in the United States." Population and Development Review, September 2000, 26(3), pp. 565-81.

Potter, C.W. "A History of Influenza." Journal of Applied Microbiology, October 2001, 91(4), p. 572-79.

Rockoff, Hugh. "Until It's Over, Over There: The U.S. Economy in World War I." NBER Working Paper No. 10580, National Bureau of Economic Research, 2004.

Romer, Paul M. "Increasing Returns and Long-Run Growth." Journal of Political Economy, October 1986, 94(5), pp. 1002-37.

Solow, Robert M. "A Contribution to the Theory of Economic Growth.” Quarterly Journal of Economics, February 1956, 70(1), p. 65-94.

U.S. Department of Commerce, Bureau of the Census. Mortality Statistics 1919. Twentieth Annual Report. Washington, DC: U.S. Government Printing Office, 1921.

U.S. Department of Commerce, Bureau of the Census. Mortality Statistics 1920. Twenty-First Annual Report. Washington, DC: U.S. Government Printing Office, 1922. 
U.S. Department of Health and Human Services.

"HHS Pandemic Influenza Plan." Washington, DC:

U.S. Government Printing Office, November 2005.

U.S. Treasury and Public Health Service. Mortality from Influenza and Pneumonia in 50 Large Cities of the United States, 1910-1929. Washington, DC:

U.S. Government Printing Office, 1930. 
